E International

\title{
Efficient Hinterland Transport Infrastructure and Services for Large Container Ports
}

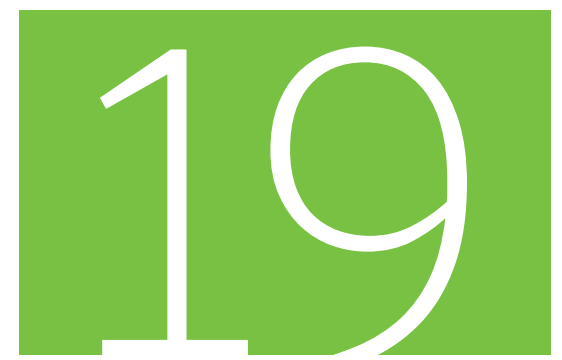

Discussion Paper 2013 19

Michele Acciaro, Alan McKinnon The Kühne Logistics University (KLU), Hamburg, Germany 


\title{
International Transport Forum
}

\section{Efficient hinterland transport infrastructure and services for large container ports}

\author{
Discussion Paper No. 2013-19
}

Prepared for the Roundtable on

RT Port Investment and Container Shipping Markets Roundtable

(7-8 November 2013, Santiago, Chile)

Michele ACCIARO

Alan MCKINNON

The Kühne Logistics University, Hamburg, Germany

September 2013 
The International Transport Forum at the OECD is an intergovernmental organisation with 54 member countries. It acts as a strategic think-tank, with the objective of helping shape the transport policy agenda on a global level and ensuring that it contributes to economic growth, environmental protection, social inclusion and the preservation of human life and well-being. The International Transport Forum organises an annual summit of Ministers along with leading representatives from industry, civil society and academia.

The International Transport Forum was created under a Declaration issued by the Council of Ministers of the ECMT (European Conference of Ministers of Transport) at its Ministerial Session in May 2006 under the legal authority of the Protocol of the ECMT, signed in Brussels on 17 October 1953, and legal instruments of the OECD.

The Members of the Forum are: Albania, Armenia, Australia, Austria, Azerbaijan, Belarus, Belgium, Bosnia and Herzegovina, Bulgaria, Canada, Chile, People's Republic of China, Croatia, Czech Republic, Denmark, Estonia, Finland, France, Former Yugoslav Republic of Macedonia, Georgia, Germany, Greece, Hungary, Iceland, India, Ireland, Italy, Japan, Korea, Latvia, Liechtenstein, Lithuania, Luxembourg, Malta, Mexico, Republic of Moldova, Montenegro, the Netherlands, New Zealand, Norway, Poland, Portugal, Romania, Russian Federation, Serbia, Slovak Republic, Slovenia, Spain, Sweden, Switzerland, Turkey, Ukraine, United Kingdom and United States.

The International Transport Forum's Research Centre gathers statistics and conducts co-operative research programmes addressing all modes of transport. I ts findings are widely disseminated and support policymaking in Member countries as well as contributing to the annual summit.

\section{Discussion Papers}

The International Transport Forum's Discussion Paper Series makes economic research, commissioned or carried out at its Research Centre, available to researchers and practitioners. The aim is to contribute to the understanding of the transport sector and to provide inputs to transport policy design.

ITF Discussion Papers should not be reported as representing the official views of the ITF or of its member countries. The opinions expressed and arguments employed are those of the authors.

Discussion Papers describe preliminary results or research in progress by the author(s) and are published to stimulate discussion on a broad range of issues on which the ITF works. Comments on Discussion Papers are welcomed, and may be sent to: International Transport Forum/OECD, 2 rue André-Pascal, 75775 Paris Cedex 16, France.

For further information on the Discussion Papers and other JTRC activities, please email: itf.contact@oecd.org

The Discussion Papers can be downloaded from:

www. internationaltransportforum. org/jtrc/DiscussionPapers/jtrcpapers.html

The International Transport Forum's website is at: www. internationaltransportforum.org

This document and any map included herein are without prejudice to the status of or sovereignty over any territory, to the delimitation of international frontiers and boundaries and to the name of any territory, city or area. 


\begin{abstract}
The growth in container volumes and the concentration of container flows on a limited number of hubs, which derives, among other things, from the increasing vessel size, requires the development of new terminal infrastructure at ports able to handle the latest generation of vessels. In addition to the pressure that such vessels impose on the terminal cargo handling capabilities, it is often forgotten, that those larger vessels will also require higher capacity in hinterland transportation or a rationalization and better use of existing transport alternatives.
\end{abstract}

Those ports that are already plagued by inland congestion or that are located in the proximity of densely populated areas, will have to come up with viable alternatives to reduce the impact of congestion and relieve local communities from the negative externalities generated by increasing cargo flows.

The development of new terminal infrastructure should then take into account the effects that increasing traffic volumes will have on the existing infrastructure and plan for expansion if necessary. As volumes increase, alternative modes of transport, such as rail or short-sea shipping are being promoted both to reduce both congestion and environmental impacts. In the specific case of Chile and the new development associated with the Puerto de Gran Escala project, it is imperative to carefully plan the development of the hinterland infrastructure. This is not only necessary to ensure that the investment yields adequate economic benefit; it must also maximise the social and environmental sustainability of the project.

This paper provides an overview of the state of the art in hinterland transport management, focusing on the challenges that the development of new container terminal infrastructure is likely to bring to the local communities. Recommendation and a set of good practice case studies of good practice are also provided.

Key words: hinterland transportation; port gate; port hinterland; rail access to terminals; container terminals, emissions. 
TABLE OF CONTENTS

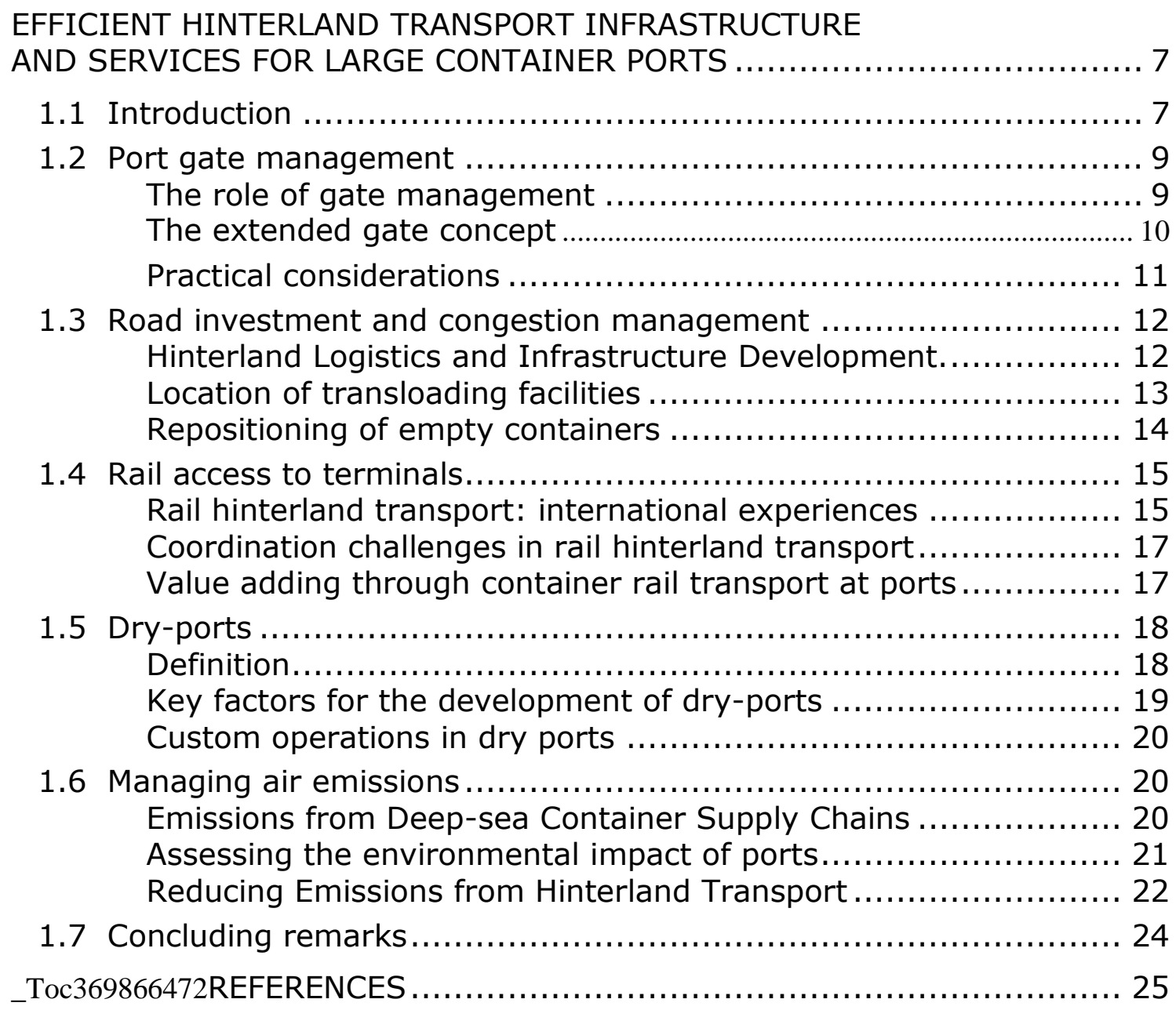





\section{EFFICIENT HINTERLAND TRANSPORT INFRASTRUCTURE AND SERVICES FOR LARGE CONTAINER PORTS}

\subsection{Introduction}

The critical role that container infrastructure plays in favouring the economic development of a country or region is well established. Infrastructure is the necessary condition for efficient cargo handling operations and adequate infrastructure is needed to avoid congestion, foster trade development as well as securing deep-sea container connectivity for economies heavily dependent on international trade. Container infrastructure, however, needs to be complemented by efficient hinterland transport connections if the port is to fully exploit its potential as growth catalyst and supply chain node (Suykens and van de Voorde 1998). Lamentably, it is not uncommon for development projects to focus exclusively on enhancing the infrastructural capabilities of the port, without adequate consideration of the hinterland connections.

The urgency of looking at port and terminal development in conjunction to their hinterland connectivity is exacerbated by the pressure on container terminals to increase their performance levels resulting from the rapid growth of containerised cargo traffic flows and their increased variability. As port capacity cannot be developed as rapidly as increases in demand (Haralambides 2002), any overcapacity is eventually exhausted and episodes of congestion ensue even in the most efficient terminals. This calls for a phased but continuous and well-coordinated effort in expanding container capacity at terminals. Terminal expansions, however, are not always matched by the expansion of hinterland connections.

Terminal operations are affected not only by the larger number of vessel calls but also by the increased variability of call sizes. As Vessels of over 15000 TEU are becoming increasingly common, despite the fact that they may only be able to access a few large hubs (Cullinane and Khanna 1999). This will concentrate container flows on a few megaports, in turn impacting berth and crane productivity of the terminal and adding pressure on hinterland links, often with adverse effects on congestion and the environment (Yap and Lam 2013).

The expected increase in transhipment associated with larger vessel size, is likely to impact on the terminals not only forcing them to handle higher volumes in the same period of time, but also to reduce the variability of their operations (i.e. increase reliability) in order to guarantee seamless flows of cargo among transhipment ports and/or transhipment port and feeder ports (Gilman 1999). The increases in productivity and reliability at terminals will require more tracking, greater container visibility and more emphasis on environmental and regulatory compliance particularly as terminals now occupy critical positions the supply chain (Notteboom 2008). 
Terminals are increasingly requested to act as buffers and accommodate the requests of their clients (i.e. primarily the shipping lines) concerning last minute schedule changes, delays, break of calls, yard storage, etc. (Notteboom 2006). All these changes take place against the background of ever increasing competition among terminals (Heaver, Meersman and van de Voorde 2001). As logistics and hinterland transportation develop further, shipping lines may become less committed to certain terminals and instead try to secure capacity in various terminals to be able to maintain flexibility. Inefficient terminals rapidly lose their competitive edge, as slow turnaround times result in higher inventory costs and have negative repercussions for the entire supply chain (Heaver 2002).

The development of supply chain networks imposes a set of challenges for ports and terminal operators (Notteboom 2008, Heaver, Meersman and van de Voorde 2001, Song 2003). Supply chain management in fact becomes an integral part of port management, and therefore it becomes increasingly important to assess priorities in the management of container terminal process effectiveness (Brooks and Schellinck 2013). The cost reductions derived from moving production processes to low cost locations can only be enjoyed as long as the supply chains supporting these processes work. It should be stressed that logistics not only supports modern production process but it enriches them by delivering added value (Lee, Nam and Song 2012).

The major difficulty with this approach though is related to the fact that the terminal is only one of the agents involved in the supply chain (Notteboom 2008). As such its ability to create added value is constrained by the actions of the other agents in the supply chain, whether they are the shipping line, the trucking companies, the hinterland operators, the port authority or the distribution centres where the containers will be ultimately delivered (Fransoo and Lee 2012).

In recent years, the importance of framing terminals and ports in the supply chain perspective has become evident (Song and Panayides 2008). Shippers and consignees increasingly require the responsibility for all logistic activities to be assumed by global supply chain specialists and logistics integration has become a common strategy of transport providers (Frankel 1999). Robinson (2002) argues that this new paradigm ports and terminals being components of global supply chains, although enticing, is still relatively uncommon (Song and Panayides 2008, Tongzon, Chang and Lee 2009). Although ports clearly have a role to play in global supply chains, they are often unable to influence or affect chain competitiveness beyond their own boundaries (Carbone and de Martino 2003).

The development and expansion of container ports therefore needs to be supported by good hinterland transportation and adequate provisions must be made for rail or road capacity if the container terminal has to function and add value. Typically the port hinterland logistics chain processes can be segmented in terminal gate processes, the hinterland transport processes and dry ports. Hinterland transport should be divided into road, rail and inland waterways. Considering that with some noticeable exceptions, inland waterways play a limited role in most ports, less attention has been devoted to this mode (e.g. Wiegmans et al. 2004, Konings 2007, Notteboom 2007).

Each of these hinterland logistics chain components plays a critical role in ensuring that the terminal delivers its supply chain value. Hinterland chain coordination has become an even more significant attribute of the effectiveness of container terminals as social and environmental sustainability considerations are taken into account. It is only through terminal and hinterland coordination that some of the negative externalities 
associated with large container ports can be managed, as the success of the dry port concept seems to attest. Terminal managers, public authorities and logistics service providers need therefore to embed the sustainability of the container hinterland process in the terminal expansion and development plans. These processes start at the terminal gate, and include inland transport to a dry port and beyond. The rest of the paper will focus on each of the hinterland chain components, highlighting their relations with each other and with the terminal. Particular attention is paid to the role that coordination plays in these processes and what strategies can be adopted to reduce the carbon footprint of the hinterland transport chain.

\subsection{Port gate management}

\section{The role of gate management}

Container terminals are transmodal facilities whose efficiency is dependent on the execution of distinct but interconnected processes. Typically container terminal processes are subdivided into three may groups: waterside, yard and landside (Stahlbock and Voß 2008). While it is not unusual for container terminals to perform deep-sea or feeder transhipment operations, most terminals have at least a small percentage of gateway traffic, i.e. containers that are transloaded from container ships through the yard and eventually to some mode of land transport and vice versa.

The intensity and complexity of landside activities vary considerably depending on the size of the terminal, the type of transportation infrastructure available in the region and the operations technologies used on the terminal. Larger terminals tend to rely on a mix of rail, road, and, when available, barge transportation to the hinterland. Road transport, however, remains one of the main hinterland transportation modes in view of its flexibility and the possibly of trucks going virtually wherever there is a road (Veenstra, Zuidwijk and van Asperen 2012).

The port gates are one of the most critical pieces of terminal infrastructure where a large part of technical and administrative procedures take place. In addition to separating and protecting the terminal from the outside, terminal gates also act as administrative border for custom and other legal procedures and function as the interface between the terminal and the hinterland. Furthermore, since the overall efficiency of a terminal is dependent on the efficiency of its subsystems, terminals are particularly wary of delays at a gate (Zhao and Goodchild 2010). Gate operations are often the result of a coordination effort between the terminal and shippers, drayage and rail operators, freight forwarders and port authorities (Giuliano and O'Brien 2008, Chen, Govindan and Yang 2013).

For this reason the efficiency of gate operations has been investigated extensively, especially in relation to trucking operations, in the attempt to improve their performance, eliminate congestion and bottlenecks or reduce negative environmental externalities. Gate systems can be grouped in three major types: 'first come first serve', appointment systems and time window systems (Giuliano and O'Brien 2007, Chen, Govindan and Yang 2013). Most terminals use a 'first come first serve' policy, where container trucks are loaded or unloaded depending on their arrival time at the terminals. One of the major disadvantages of such method is that it often generates peaks in operations and queuing ensues (Chen, Govindan and Yang 2013). 
Terminal operators have attempted to enforce appointment systems, either offering the possibility of making an appointment, or providing penalties for operators that do not appear at the terminals at the right time(Huynh 2009, Guan and Liu 2009). While the advantages of an appointment system are easily comprehensible, its implementation in practice has been met often with scepticism. This is partly because the effectiveness of an appointment system depends on the opening hours of distribution facilities and warehouses, and to some extent to labour and road regulation (Giuliano and O'Brien 2007). The implementation of appointment systems has been often driven more by the regulator than by the industry, leading some to argue that industry self-regulation would have delivered better results (e.g. in California, see Giuliano and O'Brien 2007). In numerous cases, however, the implementation of an appointment system has brought visible benefits in terms of emission and congestion reduction (Morais and Lord 2006).

An alternative is offered by time windows systems, which have been used mostly at container terminal facilities in China (Chen, Govindan and Yang 2013, Chen and Yang 2010). The system allows a better coordination of terminal operation, that are aligned with vessel arrivals and overall would improve terminal utilisation. The terminal informs freight forwarders of a vessel arrival and allocates a time window for trucking operations. This appointment system would reduce the time containers station at the terminal and allow for better loading, as the containers are more easily identified and located at the terminal. In practice however, it appears that the system has not been able to eliminate idle time for truck operators outside the terminals (Chen, Govindan and Yang 2013).

\section{The extended gate concept}

In order to resolve the complexities associated with terminal gate management and to reduce congestion in the proximity of the port, the extended gate concept has been proposed as an alternative to direct trucking operations at the port (Veenstra, Zuidwijk \& van Asperen 2012). The extended gateway would allow truck operators to move containers to a hinterland location, ideally making use of barge or rail connection. In this way the terminal would reduce congestion at its gates as well as reducing pressure on its yard capacity. The concept has been associated with that of dry port(e.g. Roso, Woxenius \& Lumsden 2009a, Bergqvist, Wilmsmeier \& Cullinane 2013a), which will be discussed more in detail later.

At the basis of the dry-port concept is the ability to relocate some loading and unloading operations inland in order to exploit economies of scale from route density and reducing external costs (see for example Bergqvist 2012). As already highlighted by Rodrigue (1999), among others, synchronisation of container terminal activities across the supply chain allows terminals to increase their competitive advantage. The extended gate concept then is based on the possibility for the terminal to perform its gate activities at the inland terminal. The transportation to the inland terminal is then internalised by the terminal operator, which then is in a position to move larger volumes by rail or barge inland (Veenstra, Zuidwijk and van Asperen 2012).

Some of the issues associated with the extended gate concept are related to the terminal location decision the coordination of container movements (e.g. different containers arrive and are requested by their customers at different times), the connectivity of rail or barge transport, information exchanges, network design and administrative (e.g. customs) procedures. The growth of vessel sizes, as outlined in the introduction, requiring container terminals to find alternative and more innovative ways to handle container flows at the terminal gate and the extended gateway could provide a valuable option. 


\section{Practical considerations}

The efficiency and effectiveness of a gate operation system depends on the availability and characteristics of IT systems employed at the terminal, the degree of coordination and information exchange among operators, labour regulation, safety and security policy at a terminal level as well as truck labour regulation. It is expedient to focus on three main practical considerations that might affect the efficacy of specific gate management systems:

i) IT infrastructure. There is the need to provide accurate and on time information. Data exchange is instrumental not only for allowing coordination among hinterland transport actors, but also to ensure visibility in the chain for efficiency, security and planning purposes. As highlighted by Kia et al. (2000), among others, the role of ICT in terminal management is critical to ensure efficient operations. Gate systems typically operate as part of a multipoint system, where information on the container manifest, the cargo or the truck driver can be collected and linked to the terminal EDI system (Guan and Liu 2009, Huynh 2009, Zhao and Goodchild 2010). Increasingly container terminals make use of advanced identification technologies for security and efficiency reasons (Marchet, Perotti and Mangiaracina 2012, Shi, Tao \& Voß 2011, Hu et al. 2011), and these are an essential component for integration along the supply chains (Song and Panayides 2008, Marchet, Perotti and Mangiaracina 2012, Almotairi and Lumsden 2009). Challenges on the implementation of ICT at terminals and ports are well documented also in developed markets (Helling and Poister 2000), and cooperation or joint ventures might be a possible solution to reduce them (Bagchi and Paik 2001).

ii) labour regulation and trucking industry practices. The implementation of a gate appointments system that might appear as a feasible way to improve container terminal gate efficiency faces challenges often related to labour regulation, working practices in the industry and inherent difficulties in managing the process (Goel and Kok 2012a, Goel and Kok 2012b). The applications of a gate appointments scheme appear to have been more successful when there has been a stronger action from the side of the regulator (Giuliano and O'Brien 2008, van Asperen, Borgman and Dekker 2011), but in general, with a few exceptions, have not delivered the expected benefits (van Asperen, Borgman and Dekker 2011). Labour regulation and industry practices, such as opening hours of distribution facilities and customer warehousing, remain a critical factor for the efficiency of gate systems.

iii) security and custom procedures at the terminal. Security and custom regulation can impose substantial delays in the operation of the terminal and it is therefore vital that coordination with the agencies responsible for these activities is negotiated and security practices are embedded in terminal gate management. Literature now exists in the area of security for container logistics (Acciaro and Serra 2013), but major issues remain with reference to the impact of scanning procedures (Bakshi, Flynn and Gans 2011), ISPS code (Yang 2010, Lirn and Wang 2010) or terminal operation resilience (Lewis, Erera and White 2003, Yeo, Pak and Yang 2013). From the analysis of 470 container terminals it appears that security has a negative impact on the operational efficiency of terminals, especially through inspection regimes, although the nature and scale of this impact depends substantially on the type of regulation and security strategy of the terminal (Bichou 2011). 


\subsection{Road investment and congestion management}

\section{Hinterland Logistics and Infrastructure Development.}

Of the various factors influencing the competitiveness of a port, the quality of transport infrastructure across its hinterland is one of the most critical (Joint Transport Research Centre, 2008). There have been numerous examples of new port developments under-performing because of a lack of investment in supporting transport infrastructure. This is hardly surprising as good hinterland connectivity is one of the key criteria than shipping lines, shippers and logistics service providers take into accounting in deciding on their choice of port (Wiegmans et al, 2008). This connectivity can be measured in several ways, by the:

- density of inland transport networks

- accessibility to key industrial and logistical centres - measured by transit time and transport costs

- range of modal options available to carriers

- capacity of the main corridors

- reliability of deliveries across the hinterland

These aspects of connectivity are clearly inter-related. Inadequate capacity, for example, causes congestion which in turn impairs reliability. This inter-relationship between capacity, congestion and reliability is fundamental to the planning of hinterland transport networks. It has become increasingly important as a result of six major trends:

a) The tightening of logistical schedules as companies have cut inventory levels and compressed order cycle times. This has made their production and distribution systems more vulnerable to delays at a time when globalisation has extended their supply lines and made them more dependent on deep-sea container services.

b) The rapid growth in container traffic that has occurred mainly as result of trade liberalisation and the globalisation of manufacturing and procurement strategies.

c) The sharp increase in the size of container vessels which is causing inland flows to spike and create bottlenecks at weak links on hinterland networks.

d) The concentration of production capacity and inventory in fewer locations as companies seek economies of scale. This is consolidating container flows on key corridors, which often lack the capacity to cope.

e) The adoption of 'slow steaming' by container shipping lines, primarily to cut bunker fuel costs. To compensate for the lengthening of transit-times on the maritime leg, shippers are keen to accelerate hinterland transport and improve its reliability to minimise adverse effects on production and distribution schedules (Maloni et al., 2013).

f) The shift in the balance of costs between deep-sea and hinterland transport. As increasing vessel size reduces cost per TEU-km on the maritime leg, the share of total door-to-door costs attributable to hinterland transport increases (Notteboom 2008). The share is further inflated by rising energy prices (as the energyintensity of hinterland transport is significantly higher than of deep-sea shipping) and deteriorating reliability on congested hinterland networks. 
These trends emphasise the importance of logistics to the planning of hinterland transport, a subject that has attracted significant academic attention over the past decade (e.g. Notteboom and Rodrigue 2007, 2008). Much has been written about the transformation of ports from basic transport terminals to supply chain hubs in an effort to extend their range of value-adding services (e.g. Carbone and de Martino 2003). In pursuit of added value shipping lines have also diversified into land-based logistics. Another aspect of this 'logistification' of maritime transport, which has so far generated less interest, is the alignment of hinterland infrastructure planning with the changing geography of companies' logistics systems (McKinnon 2010). In many countries the interface between the container shipping network and shippers' supply chains has been changing, altering the pattern of container movement within national markets. As Hall and Jacobs (2010) argue, keeping ports competitive in this new regime requires 'coordinated action, both within existing supply chains and between competing supply chains that share the same port-hinterland spaces and infrastructure' (p.1113).

The pattern of container movement is largely shaped by the locations at which containers are loaded and unloaded (so-called 'transloading' locations) and the repositioning of empty containers within the hinterland either to collect an export consignment or to be returned to a port for global redistribution.

\section{Location of transloading facilities}

The very essence of containerisation is to allow goods to move in sealed, standardised modules on a door-to-door basis. The location of these 'doors' is changing, however, as companies modify the points in their supply chains at which the containerisation and 'decontainerisation' operations occur. Recent research in the UK has found that the vast majority of inbound containers are bound for general distribution centres (DCs) or dedicated DCs for imported goods, located at strategic locations for national and regional distribution within the country. Deviations from this pattern are beginning to emerge, however. For example:

i) Port-centric logistics: this concept applies mainly, though not exclusively, to inbound container traffic and involves 'destuffing' the container at a DC in the vicinity of the port (Mangan et al. 2008). The imported goods are stored and handled there and subsequently distributed in conventional trucks or rail wagons to customers across the hinterland. PCL has been heavily promoted in recent years by port authorities and property developers, particularly in the UK and US, and is well-exemplified by the new $\$ 2$ bn London Gateway port developed by DP World in the Thames estuary. When fully developed, this port will combine a six-berth container terminal and adjoining 450 hectare distribution park.

PCL confers advantages on port authorities, shipping lines and shippers. For port authorities it offers a means of exploiting unused land, diversifying into value-adding logistics services and securing greater shipper loyalty. Shipping lines can accelerate container turnaround times and, in the case of countries with unbalanced container flows, minimise empty container movement across the hinterland. Shippers can distribute their products more directly from port-based DCs, eliminating links in the supply chain, reducing inland transit times and sometimes taking advantage of lower cost land. Again these advantages, however, shippers must weigh the disadvantages of siting a DC in a location peripheral to the national market and making a long-term commitment to a particular port's portfolio of container services. Peripherality will be less of a problem where the port is located close to a major concentration in population / industry, as in the case of London Gateway, and where most, if not all, of the products stored and 
handled by the port-based DC pass through the port. Where the DC also draws products from many other sources a port-based location may be sub-optimal relative to a more centrally-located facility (Monios and Wilmsmeier 2012).

Wide adoption of the PCL model would have significant implications for transport infrastructure development. The clustering at a port of DCs providing radial distribution across a national market would require good multi-directional road, and possibly rail, access. Unlike the traditional hinterland movement of containers to inland terminals and dry ports, which involves channelling container flows along strategic corridors to major hubs, deliveries from DCs are typically much more dispersed to final points of sale and use. The transloading of freight from containers to articulated trucks also tends to increase total cube, partly because of the greater use of unitised handling equipment in land-based logistics but also because the density with which products are packed into deep-sea containers is generally higher than that on surface transport. It can therefore require several trucks to distribute a single container-load of densely-packaged imports (McKinnon 2013).

PCL also has implications for freight modal split in the port hinterland. For example, the replacement of container flows with the movement of freight emerging from portbased DCs in loose or palletised form can make it more difficult for rail to compete. The greater dispersal of hinterland deliveries from these DCs can also make it difficult for railfreight operators to consolidate flows into viable train-loads, particularly within the tight delivery schedules imposed on wholesale and retail supply chains downstream of the port. In most countries, the railways command a smaller share of freight movement at the 'secondary distribution' level outbound from DCs than at the primary level feeding product into factories and DCs. All of this suggests that PCL may tilt the hinterland mode split in favour of road, though this has still to be confirmed empirically.

ii) Consolidation of container loads: another logistical trend which is evident in both exporting and receiving markets is the channelling of maritime freight through inland consolidation centres to improve levels of container fill and increase opportunities for the backloading of containers. Major retailers sourcing products from numerous suppliers in a given market are increasingly consolidating less-than-container loads ( $L C L$ ) at hub locations. Similarly, manufacturers with numerous production and warehouses sites, from which container flows were traditionally unco-ordinated, are now establishing hubs through which deep-sea freight can be bundled into more viably-sized container loads. This yields a net reduction in ocean freight costs despite the fact it adds an extra node and link to the maritime supply chain. It can also increase the opportunities for shifting freight to rail (or inland waterway) by aggregating container flows into train or barge loads. This modal shift effect is reinforced where several companies cluster their 'maritime hubs' at locations with good access to rail and waterway networks.

\section{Repositioning of empty containers}

Marshalling the stock of empty containers is one of the greatest challenges of containerisation. In almost every country it is considered very inefficient, though the degree of sub-optimality is very difficult to assess given the lack of data on empty container movements. It is common, for example, for containers emptied at an import location to be returned to the port prior to despatch to an export location to collect its next load. Where 'triangulation' occurs within the hinterland, the routing is often needlessly circuitous. Even where container loads are received and generated by the same factory or warehouse, the chances of an inbound container being reloaded with an export consignment are often quite limited. As a result of these practices: 
- container turnaround times are lengthened

- shippers are often unable to get an adequate supply of the specific types and sizes of container they require when they need them

- much unnecessary transport is generated across the hinterland, increasing traffic levels, costs and emissions.

Inefficiency in the landward repositioning of empty containers has persisted for a several reasons, including poor IT, the refusal of shipping lines to share boxes, tight demurrage restrictions and a general lack of co-ordination between stakeholders. The concept of the 'grey box' has long been advocated as a means of pooling empty container capacity and thus rationalising the movement of empty containers across hinterlands. There are few examples, however, of it being successfully or sustainably applied. The adoption of PCL would also help to ease the empty repositioning problem, though, as discussed earlier, this may prove to be attractive to limited numbers of companies with specific logistics requirements.

An alternative, or supplementary, option would be to use some of the empty container capacity in the domestic distribution of industrial and retail supplies. This would entail greater integration of maritime and domestic logistics within the port hinterland and some relaxation of current restrictions on the use and return of containers. It could lead to containers being increasingly used to carry domestic loads on routes back to the port or to an export location. In those countries where much of the hinterland movement of containers is handled by merchant haulage, shippers have a strong interest in maximising revenue from container repositioning trips, incentivising them and their carriers to find backloads. Online load matching sites can facilitate the search for suitable backloads, though the deployment of empty container capacity in domestic logistics also requires the adaptation of handling systems and reception bays at industrial and commercial premises. Overall, as in so many aspects of hinterland transport, there would be a need for much greater co-ordination between all the relevant actors to take full advantage of this proposal (van der Horst and de Langen 2008).

Rationalisation of the movement of empty containers across the hinterland would ease infrastructural pressures on key routes to and from the port, particularly where repositioning regularly entails the routing of boxes via the port terminal.

\subsection{Rail access to terminals}

\section{Rail hinterland transport: international experiences}

In order to reduce congestion on road transportation and to exploit the economies of traffic density one of the solutions that is most often advocated is to increase the share of rail and inland waterways to that of trucks. These two alternative modes of transport offer substantial cost and environmental advantage, but are generally less flexible and require increased coordination as multiple private operators and public agencies need to cooperate harmoniously. This coordination does not come about spontaneously, but requires specific policy action (van der Horst and de Langen 2008).

Given the complexity of rail coordination, the potential for a switch to rail for transportation to/from container terminals is dependent on the institutional model that is used for rail in a particular country. Railway infrastructure and operational configurations typically are subdivided on the basis of the degree of geographical and functional integration (Pittman 2007). While there are arguments in favour and against various 
institutional configuration models, in the specific case of railway access to container terminals the development of dedicated freight corridors often requires the agreement of multiple actors, network operators and the infrastructure developer. Furthermore, in case a mixed network, i.e. networks that cater simultaneously for passenger and freight transport, the relations with the passenger rail operator can become a critical factor.

In Europe, policy has aimed at separating infrastructure management from passenger and freight operation, in the attempt to overcome the natural monopoly held by nation-wide integrated rail networks. The transition from national railway monopolies to an integrated network of nationally-managed infrastructure and European-wide rail operators is far from completed. The reform has favoured the development of dedicated railway companies especially in the vicinity of larger ports. The number of container shuttle services has been rising and is expected to increase in response to environmental and economic pressures. In particular the development of dedicated freight corridors, such as the "Betuwe Route" in the Netherlands, with more than 350 trains per week, or the "Iron Rhine" in Belgium, that contributes to the 200 container trains departing from Antwerp weekly, aim at improving the conditions for rail transportation (Meersman et al. 2008).

A particularly successful case relates to the development of hinterland cargo movement by rail from the port of Hamburg and Bremen to their hinterland. In Hamburg the port railways network is managed by the Port Authority and is responsible for the movement of 2 million TEU along the $300 \mathrm{~km}$ network(Free and Hanseatic City of Hamburg and Hamburg Port Authority 2012). 92 operators are licenced to use the port rail infrastructure and this accounts for over 30 per cent of Hamburg container flows handled by rail (against the $10 \%$ handled by Rotterdam and Antwerp). The port is handling today approximately 200 train per day that are expected to double in the next decade. The port of Bremerhaven has the highest percentage share of container rail transport, with over 45 per cent of container throughput being moved inland by rail.

In the case of Russia, railway reform is currently underway, with the intention of establishing some form of vertical restructuring and some cross-subsidisation between freight rail transport, currently responsible for the very high utilisation of railways in Russia and passenger transport (Pittman 2004). The intention behind rail reforms in Russia, and elsewhere, are lowering national government contributions to the sector, increasing the sector efficiency and providing competitive options for shippers (Pittman 2013). It is particularly interesting to notice the development of the container infrastructure between the recently built port of Ust Luga and the Predportovy Distriport and Interterminal Predportovy, as well as other logistics facilities in the area (Korovyakovsky and Panova 2011).

The penetration of rail transportation in Asia has not followed the same pattern around the continent with marked differences between the systems used in China, India and South-East Asia. While rail transportation does not show the same degree of efficiency as in other parts of the world, intermodality is becoming increasingly important. The development of Chinese dry-ports is still hindered by congested infrastructure and administrative inefficiencies (Beresford et al. 2012). The Indian case is characterised by congestion and a very fragmented logistics infrastructure ( $\mathrm{Ng}$ and Gujar 2009, Haralambides and Gujar 2011) with virtually no rail transportation in South-East Asia. 
In North America, rail transportation has for long constituted the backbone of freight movement and the development of an integrated network of dry ports. In particular, the development of freight hubs, such as Chicago, has been made possible by the affordable and reliable rail freight transport connecting large ports to inland satellite terminals and load centres (Rodrigue et al. 2010). Issues related to capacity constraints and the difficulties in coordinating expansion among the seven main independent rail operators and the transmodal challenges in Chicago, have started to affect the efficiency of the system (Rodrigue and Notteboom 2010).

In the South American railway sector reform has been carried out extensively and completed by the nineties, with Mexico and Argentina leading the way, with Brazil following in more recent times. The system has been characterised by the preference for vertically integrated railroad concessions. The main challenges in those countries for the attractiveness of railway in terms of freight corridors seems to be related to the very high intermodal competition as well as the management of access rights to the main ports, e.g. Santos in Brazil (Estache, Goldstein and Pittman 2001, Padilha and Ng 2012).

\section{Coordination challenges in rail hinterland transport}

As shown in the geographical review of the previous section, coordination in hinterland railways does not come about spontaneously, but requires specific policy action. As van den Horst and de Langen (2008) explain, difficulties in coordination emerge as a result of the multiple actors being involved in developing and planning of container rail transport infrastructure.

Van den Horst and de Langen (2008) list some of the coordination problems arising in container rail transport, specifically: unused capacity and congestion, often combined in the peak-load problem, delays due to limited planning on rail terminals, and limited exchange of traction and of rail cargo. They also suggest four major ways in which such coordination can be improved:

- Introduction of incentives: through the development of a reward or penalty systems, differentiated tariffs or capacity auctioning;

- Creation of inter-firm alliances: through joint ventures, project specific contracts or other forms of vertical cooperation along the chain;

- Organisation scope change: introduction of mechanisms for risk sharing or integration along the chain;

- Collective action: through governmental intervention or private intervention.

\section{Value adding through container rail transport at ports}

In order to understand the challenges associated with the use of container terminal transportation by rail to and from the hinterland of a port, it is important to distinguish between three interlinked but distinct issues:

i) Value for the users. Container rail transportation will be valuable as long as shippers can gain some form of benefit from using rail transport. In recent years the question of the competitiveness of intermodal chains has emerged. In addition to clear environmental benefits that can be obtained from using rail transportation, the question remains about whether reliability and cost savings can compensate for the greater flexibility offered by road transportation. 
ii) Rail service quality and price. The attractiveness of the rail link depends on the pricing policies, the quality of the service and the conditions under which the rail connection is provided. Pricing policies for rail connections are difficult to formulate and typically do not allow for full infrastructural cost recovery. The efficiency of the network, access to terminals and shunting yards, and the interaction with other parts of the network are also likely to influence the reliability and effectiveness of rail transport. In particular marshalling and switching infrastructure, signalling and the degree and availability of electrified tracks and terminals are some of the aspects to be considered to assess the attractiveness of the rail and rail terminal facilities.

iii) Rail network development and financing. Given the costs associated with the development of railroad infrastructure, the model employed to build and finance the network is also likely to have an impact on operation. While the use of public private partnerships appears quite successful in the development and management of road infrastructure, its implementation in the case of rail or other intermodal infrastructure has been less encouraging. This implies that the development of new freight rail infrastructure typically require a certain degree of public funding. This is particularly true in the case of vertically separated railroad networks. Dedicated rail corridors in areas with predictable and stable volumes might prove more attractive, but typically infrastructure recovery times are longer than what the private sector is willing to accept and, given the economies of scale associated with rail infrastructure development, private financing may result in under-provision or under-maintenance (Monios and Lambert 2013).

\subsection{Dry-ports}

\section{Definition}

The definition of dry ports is rather ambiguous and has been used to indicate any sort of transmodal facility from simple inland container deposits to advanced intermodal distribution and logistics parks. Roso et al. (2009b), define a dry port as an inland intermodal terminal directly connected to seaport(s) by rail where customers can collect or deliver their cargo as if at a seaport. This definition implies, and in this sense is more restrictive than that of intermodal freight terminal advanced for example by UNECE (1998), that there is a conscious and coordinated effort to provide similar services at the dry-port as at the seaport (Roso and Rosa 2012).

The advantages of dry ports stem from their ability to reconfigure inland transport networks improving supply chain performance, boosting local competitiveness and reducing negative externalities (Bergqvist, Wilmsmeier and Cullinane 2013b). One of the key features of dry ports is their intermodal character, as they allow for the exploitation of economies of flow density and the ability to use rail or inland waterway transport. They also act as logistics buffers, in particular in those areas where logistics terminals at ports are required to reduce container dwell times for efficiency reasons or lack of capacity, such as in the Hamburg-Le Havre port range (Veenstra, Zuidwijk and van Asperen 2012) or in major Chinese ports (Beresford et al. 2012).

The development of inland intermodal terminals is, however, not an effortless endeavour, as is often the case when their establishment falls under the responsibility of local authorities. In most dry port development experiences there is some form of governmental intervention, often in partnership with private operators (Bergqvist 2008). 
The interaction of public and private actors often requires innovative pricing and financial schemes (Monios and Lambert 2013), and may add to the coordination challenges associated with the use of intermodal transport.

\section{Key factors for the development of dry-ports}

The development of the dry port has taken different forms globally, and although some general characteristics still exist, the local context plays a critical role in the success of a dry port development project (see Bergqvist, Wilmsmeier and Cullinane $2013 a$ for an overview of global experiences). Among the common characteristics at the basis of the successful development of dry ports, Bergqvist (2013) makes the following observations on the basis of a series of research projects

a) The intermodal facility needs to be developed where there is a market potential. Dry ports with higher profitability tend to be developed faster and put pressure on the public authorities and secure financing.

b) The development of the dry port often requires public support in forms of subsidy and risk mitigation. The different financial perspectives of private and public actors should also be taken into account, as the financiers will have different investment time horizons.

c) It is often instrumental for the success of a dry port to receive the support of local entrepreneur or public official that can ensure momentum in the development of the logistic concept is not lost. Collaboration among logistics and transport service providers, local and national authorities, manufacturing and distribution facilities is important, As with the case of the development of new container terminal infrastructure, political pressure can interfere with the development process, in some cases delaying or hindering the establishment of a dry port. Political pressure derives from the fact that often the catchment area benefiting from a dry port beyond municipal (and in some cases national) borders, therefore triggering, especially in period of political instability, e.g. at election times, conflicts on the location of the dry port. However, as pointed out for ports by Benacchio et al. (2001), the opposite reaction is also possible, with the development of new infrastructure being resisted on environmental or social grounds.

d) The attitude and overall strategy of the local and national administration is also crucial in the success of a dry port development .

e) As highlighted in the previous section the efficiency of the rail (or barge) transport services is critical in establishing and maintaining the competitiveness of the dry port and any connected distribution facility.

f) The operational characteristics of the terminal in terms terminal layout, terminal infrastructure, road configuration, IT and security infrastructure determine the efficiency of terminal operations. For the dry port to achieve its efficiency targets, this infrastructure has to be in place and adequate maintenance provisions need to be made.

g) From a more administrative and organisational perspective newly developed dry ports need to have a clear ownership structure and transparent organisation. This ensures long-term credibility and reduces risk exposure to the users. Such transparency and openness conditions can be stipulated in the contractual agreements governing the public private partnership. 
h) The practice of tendering has generated improvements in the level and pace of innovation, but has also required a clearer statement on the expectations of the local authorities, the pricing and leasing policies allowed, contract characteristics and risk sharing agreements.

\section{Custom operations in dry ports}

The impact on operations of custom clearance procedures at ports and in transportation is well established (Clark, Dollar and Micco 2004, Haralambides and Londoño-Kent 2004), and one of the main advantages of dry port is the possibility of concentrating custom inspections outside of the seaport terminals (Roso 2008, Roso, Woxenius and Lumsden 2009b). One of the first definitions of dry ports, Inland Clearance Depot, (UNECE 1998) specifically accounted for the provision of customs clearance services. These facilities are defined as inland intermodal terminals dedicated to the handling and storage of goods under custom transit. The typology of operations performed in dry ports differ globally but typically include good clearance for temporary storage for onward transit, export, warehousing or import (Roso and Lumsden 2010).

The provision of custom clearance and quarantine services imposes high security procedures for accessing the dry port, similarly to seaports, and depending on the country may include high fencing, cameras and guards. However the uptake of custom clearance services shows marked differences among countries as insurance policies and customer habit or preference might interfere with the service use. Security issues can also affect the demand for clearance services or the use of the dry port itself.

Little attention has been paid to the link between port and maritime security and the hinterland transportation networks (Schilk et al. 2007). Schilk et al. (2007) highlight how security at a chain level even for European transport requires further improvements and recommend the development of innovative security strategies and concepts combining maritime with hinterland transport to crate seamless security processes.

\subsection{Managing air emissions}

\section{Emissions from Deep-sea Container Supply Chains}

It is estimated that shipping accounts for around 3\% of global greenhouse gas emissions (IMO 2009), with container ships responsible for approximately a third of this total (Buhaug et al. 2009). These figures relate solely to emissions from the vessels and exclude the environmental impact of ports and hinterland transport. On an intercontinental door-to-door container movement, the deep-sea leg is usually the largest contributor to total carbon emissions, though hinterland transport can represent $20-30 \%$ of this total depending on the choice of transport mode (Woolford and McKinnon 2011a). Direct emissions from the port are relatively insignificant, typically contributing $1-2 \%$ of the total. It would be wrong, however, on the basis of this estimate, to dismiss the contribution that ports can make to environmental improvement in a container supply chain. 


\section{Assessing the environmental impact of ports}

It is the ships visiting the ports, rather than port activities themselves that are the main sources of pollution and the main concern is over pollution by noxious gases rather than $\mathrm{CO}_{2}$ emissions. The dirty bunker fuels ships typically burn emit large quantities of sulphur dioxide, nitrogen oxide and particulate matter in the vicinity of the port, exposing population in the surrounding areas to high and unhealthy concentrations of these noxious gases (California Air Resources Board 2006; Berechman and Tseng 2012). As road transport has traditionally used lighter, cleaner fuels and been subject to much stricter emission controls than shipping, a wide gap exists in the tolerated levels of pollution from these two modes. For example, standard bunker fuel contains on average around 27,000 parts per million (ppm) of sulphur by comparison with the $10-15 \mathrm{ppm}$ found in the fuels used by road vehicles in Europe and the US (International Council for Clean Transportation, 2007). Global efforts to reduce levels of maritime pollution, mostly administered by the IMO under its MARPOL programme, have made limited progress over the past few decades, leaving it to ports to take the environmental lead and try to improve air quality for their local populations. They can do this, for example, by requiring vessels to switch to cleaner, lower-sulphur diesel fuels as they approach the port and by providing shore-side electricity to ships when moored by a practice known as 'cold-ironing. By installing 'scrubbers' to capture sulphur emissions some vessels have been able to meet air quality restrictions while continuing to burn bunker fuel. Several Sulphur Emission Control Areas (SECAs) have also been established around world (e.g. on the Californian coast, the Baltic and North Sea) to reduce the permitted level of sulphur emissions in ship exhaust fumes. Modernisation of the fleet with larger, cleaner, more fuel-efficient vessels is also cutting emission levels per TEU or tonne transported, but the longevity and slow replacement rate of ships makes this a relatively slow process.

On the landward side, some ports have introduced 'clean trucking' schemes. The port of Vancouver, for example, has a Truck Licensing Scheme that restricts access to the port to less polluting vehicles (Braathens 2011). Efforts have also been made to reduce the queuing of trucks coming to collect containers, though this has not always translated into emission reductions (Giuliano and O'Brien 2007). Some ports with the necessary infrastructure are promoting a modal shift to rail and waterborne transport. The Port of Rotterdam, for example, is planning to shift much of its hinterland container traffic from road to rail and barge by 2030 , changing the proportion of containers moved by these modes from, respectively, $49 \%, 37 \%$ and $14 \%$ in 2007 to $35 \% .45 \%$ and $20 \%$ in 2030 (Braathens 2011). This is one respect in which the environmental leverage of a port can extend well beyond the direct emissions from port handling activities. By offering a competitive range of rail and waterborne services, which emit much less noxious pollutants and $\mathrm{CO}_{2}$ per TEU- or tonne-km than road, a port can significantly reduce the environmental impact of the wider container supply chain.

Ports currently have little incentive to do so, however, because for environmental reporting purposes the boundary is usually drawn quite tightly around the port's activities. The Port of Long Beach is one of the few to report its carbon footprint within boundaries of differing extent. The first is the perimeter of the port, enclosing activities performed directly on-site. The second extends 24 nautical miles out to sea to include emissions from approaching and departing vessels within US territorial waters. The third also pushes the boundary inland to the State border (Port of Long Beach, 2009). Table 1 shows how the carbon emissions per TEU expands as the boundary is extended. 
Table 1. Effect of extending the reporting boundary on calculated $\mathrm{CO}_{2}$ emissions from Long Beach Port

\begin{tabular}{|l|l|}
\hline $\mathbf{C O}_{2}$ Reporting Boundary & $\mathbf{k g ~} \mathbf{C O}_{2}$ per TEU \\
\hline Container handling only & 16 \\
\hline Ocean going vessels included from 24 nm offshore & 36 \\
\hline $\begin{array}{l}\text { All port activity, off-shore shipping and transport to state } \\
\text { border }\end{array}$ & 119 \\
\hline
\end{tabular}

For this to be more than an analytical exercise, the boundary should reflect the amount of influence a port authority can exert over the level of emissions beyond its immediate territory. In most cases this influence is very limited, though as part of a multi-stakeholder initiative a port authority or terminal operator can play an important role in 'greening' the maritime supply chain. In the absence of this broader perspective, conflicts can arise between the environmental interests of the various parties. For example, transhipping a container from a ship to a train in a port terminal can emit significantly more $\mathrm{CO}_{2}$ per TEU than transferring it to a truck, depending on the nature of the terminal layout and handling equipment. A terminal operator wishing to minimize its carbon footprint might therefore prefer to promote dispatch by road, whereas on a doorto-door basis emissions would be much lower if rail were used (Woolford and McKinnon 2011b).

Although ports are directly responsible for a very small percentage of the $\mathrm{CO}_{2}$ emitted by the typical deep-sea container supply chain, many are refining their measurement of these emissions, setting ambitious targets for reducing them and implementing a range of decarbonisation measures (European Sea Ports Organisation 2012). For example, by electrifying its rubber-tyred gantry cranes, the Port of Hong Kong (2012) has been able to reduce average $\mathrm{CO}_{2}$ emissions per container moved by roughly $60 \%$. While such savings in carbon emissions are welcome they can be far exceeded by improvements in the environmental performance of hinterland transport.

\section{Reducing Emissions from Hinterland Transport}

These emissions can essentially be reduced in five ways:

1. Rationalising the pattern of container movement

2. Shifting container traffic to lower carbon transport modes

3. Improving the loading of vehicles, wagons and barges carrying containers

4. Increasing the energy efficiency of the transport operations

5. Powering these operations with cleaner, lower-carbon fuels.

1. Rationalising the pattern of container movement: As discussed in Section 2, the amount of vehicle movement per container load within the hinterland can be reduced in various ways. This can be done by reducing the number of links in the container supply chain by, for example, adopting a port-centric logistics strategy (McKinnon 2013) and repositioning empty containers directly from import to export locations rather than via the port ( $\mathrm{Ng} \mathrm{2012).} \mathrm{Even} \mathrm{where} \mathrm{the} \mathrm{number} \mathrm{of} \mathrm{links} \mathrm{remains} \mathrm{constant,} \mathrm{containers} \mathrm{can} \mathrm{be}$ more efficiently routed between the various handling and storage nodes in the chain. The resulting reduction in the transport intensity of container distribution translates directly into lower emission levels. 
2. Shifting container traffic to lower carbon transport modes: In most cases this entails a switch from road to rail, though in some countries, such as Belgium and the Netherlands, inland waterways and coastal shipping provide an important hinterland feeder service. Typically rail and waterborne transport emit between $25 \%$ and $50 \%$ of the $\mathrm{CO}_{2}$ emissions per TEU of a trucking operation. The magnitude of their environmental advantage depends on a series of factors which vary internationally, including:

- the degree of rail-freight electrification and carbon intensity of the electricity used

- restrictions on the weights and dimensions of the relevant trucks, trains and barges

- the relative vehicle age and emission profiles of the various modes

- the relative density of the different modal networks

- the number and locations of intermodal terminals, including dry ports

The last of these factors is particularly important as rail and waterway services very seldom provide a door-to-door service and must rely on road feeder movements. This generally makes the freight movement more circuitous and erodes some of the environmental benefit of using rail or water (McKinnon 2011). Nevertheless, the use of intermodal services can still yield substantial reductions in truck-kms, fuel use and emissions (Department for Transport 2011). The channelling of container flows by rail to an inland 'dry port', rather than by road, has also been shown to offer large $\mathrm{CO}_{2}$ savings (Rosa 2007).

3. Improving the loading of vehicles, wagons and barges carrying containers: If one takes the internal loading of the container as given and measures capacity utilisation on a TEU basis, significant potential exists for raising load factors. A survey of container trains leaving UK deep-sea ports found that, on average, only around $62 \%$ of the available slots on existing services were filled (Woodburn 2011). In some European countries, 13.6 metre trailers carrying $20 \mathrm{ft}$ ( 6 metre) containers are quite a common sight. Relaxing restrictions on truck length, for example, from 16.5 to 25 metres allows hauliers to combine a $40 \mathrm{ft}$ and $20 \mathrm{ft}$ container on the same vehicle, significantly cutting emissions relative to moving them in two separate vehicles. This, however, conflicts with the modal shift objective, as it substantially improves the price competitiveness of trucking, and can cause a net increase in emissions where much of the rail-based container traffic migrates to road (Knight et al. 2008). Where rail infrastructure permits, as in the US and Canada, double-stacking of container trains not only cuts emissions per ton-mile for existing rail traffic, as measured by Forkenbrock (2001), but also helps rail to expand its share of the hinterland transport market.

4. Increasing the energy efficiency of hinterland transport operations: Extensive research has been done on the opportunities for improving the energy efficiency of freight transport, most of which would apply as much to containerised traffic as to other forms of goods movement (e.g. Vyas et al. 2013). Much of this research has focused on the trucking sector which is understandable as it is by far the dominant freight mode and is more energy-intensive than rail and waterborne modes. A common finding of these studies, particularly those on road freight, is that there is a broad suite of technological, operational and behavioural measures available to cut energy consumption, ranging from driver training through aerodynamic profiling to the redesign of the vehicle engine and transmission systems (e.g. Aecom 2008). 
5. Powering these operations with cleaner, lower carbon fuels: Like the previous measure, switching to alternative fuels is a means of decarbonising all forms of freight transport and has no special relevance to the hinterland transport of containers. The potential reductions in noxious and greenhouse gas emissions from freight operations achievable through 'repowering' with alternative fuels are discussed by Leonardi et al. (2013).

\subsection{Concluding remarks}

The development of container terminal capacity needs to be complemented by the expansion of the hinterland links in order to enhance supply chain value creation and reduce external costs associated with increasing container flows. The importance of adequate hinterland infrastructural capabilities and efficient transport services to and from container terminal facilities cannot be over-stressed, especially in view of the global trends towards larger container vessels, mounting inter-terminal competition and increasing requirements for supply chain effectiveness.

This review paper has focused on hinterland transportation and services, analysing the various components of inland container transport where improvements can accompany container port expansions. As in the end it is the efficiency of the entire container supply chain, from shipper to consignees, that matters for the success of a container port inadequate hinterland infrastructure and services can be a major bottleneck. The paper argues that substantial improvements are possible in the interfaces between the container terminal and the inland transport modes, and through a better use of road and rail transport involving for example dry ports and empty container management.

The increasing importance of sustainability considerations in container supply chains also requires terminals and infrastructure development authorities to take more account of emissions and other external effects, so that the externalities can be actively managed and the economic benefits of increased connectivity are balanced against societal and environmental costs.

The paper identified three main segments of the hinterland supply chains and their corresponding infrastructure, that affect the ability of container terminals to create supply chain value: the container gate systems, hinterland transport by road or rail, and dry ports. Each of these hinterland chain components are characterised by specific policy, management and environmental challenges, but a tendency that is common to all is the increasing need for coordination to minimise the risk of bottlenecks developing. It is only through a concerted effort among container terminals, local and national authorities, private road hauliers and railroads operators, as well as dry port managers and freight forwarders that the benefits of new infrastructure both at the port and inland can be maximised. 


\section{REFERENCES}

Acciaro, M. and Serra, P. 2013, "Maritime Supply Chain Security: A Critical Review", in IFSPA 2013, Trade Supply Chain Activities and Transport: Contemporary Logistics and Maritime Issues, pp. 636.

Aecom 2008. Reducing Greenhouse Gas Emissions from Heavy-Duty Vehicles, Report for the European Commission, Brussels.

Almotairi, B. and Lumsden, K. 2009, "Port logistics platform integration in supply chain management", International Journal of Shipping and Transport Logistics, vol. 1, no. 2, pp. 194-210.

Bagchi, P.K. and Paik, S. 2001, "The role of public-private partnership in port information systems development", International Journal of Public Sector Management, vol. 14, no. 6, pp. 482-499.

Bakshi, N., Flynn, S.E. and Gans, N. 2011, "Estimating the operational impact of container inspections at international ports", Management Science, vol. 57, no. 1, pp. 120.

Benacchio, M., Ferrari, C., Haralambides, H.E. and Musso, E. 2001, "On the economic impact of ports: local vs. national costs and benefits", Forum of Shipping and Logistics, Special Interest Group on Maritime Transport and Ports International Workshop, pp. 8.

Berechman, J. and Tseng, P-H. 2012, "Estimating the environmental costs of port related emissions: The case of Kaohsiung" Transportation Research D, 17, 35-38.

Beresford, A., Pettit, S., Xu, Q. and Williams, S. 2012, "A study of dry port development in China", Maritime Economics and Logistics, vol. 14, no. 1, pp. 73-98.

Bergqvist, R. 2008, "Realizing logistics opportunities in a public-private collaborative setting: The story of Skaraborg", Transport Reviews, vol. 28, no. 2, pp. 219-237.

Bergqvist, R. 2012, "Hinterland logistics and global supply chains" in Maritime Logistics:

A Complete Guide to Effective Shipping and Port Management, eds. D. Song and P.

Panayides, Kogan Page Publishers, , pp. 211-232.

Bergqvist, R. 2013, "Hinterland Transport in Sweden: The Context of Intermodal

Terminals and Dry Ports" in Dry Ports - A Global Perspective, Challenges and

Developments in Serving Hinterlands., eds. R. Bergqvist, G. Wilmsmeier and K.

Cullinane, Ashgate Publishing Ltd., Farnham, pp. 13-28.

Bergqvist, R., Wilmsmeier, G. and Cullinane, K. (eds) 2013a, Dry Ports - A Global

Perspective, Challenges and Developments in Serving Hinterlands., Ashgate Publishing Ltd., Farnham.

Bergqvist, R., Wilmsmeier, G. and Cullinane, K. 2013b, "Introduction-A Global Perspective on Dryports" in Dry Ports - A Global Perspective, Challenges and Developments in Serving Hinterlands., eds. R. Bergqvist, G. Wilmsmeier and K. Cullinane, Ashgate Publishing Ltd., Farnham, pp. 1-10.

Bichou, K. 2011, "Assessing the impact of procedural security on container port efficiency", Maritime Economics and Logistics, vol. 13, no. 1, pp. 1-28. 
Braathens, N.A. 2011, "Environmental Impact of Shipping: Role of Ports' OECD, Paris. Brooks, M.R. and Schellinck, T. 2013, "Measuring port effectiveness in user service delivery: What really determines users' evaluations of port service delivery?", Research in Transportation Business and Management, .

Buhaug, $\varnothing$. et al. 2009, 'Prevention of Air Pollution from Ships: second IMO GHG Study' International Maritime Organisation, London.

California Air Resources Board 2006, "Quantification of the Health Impacts and Economic Valuation of Air Pollution from Ports and Goods Movement in California" Appendix A in "Emission Reduction Plan Ports and Goods Movement in California." California Air Resources Board.

Carbone, V. and de Martino, M. 2003, "The changing role of ports in supply-chain management: an empirical analysis", Maritime Policy and Management, vol. 30, no. 4, pp. 305-320.

CE Delft 2012, "Potential of Modal Shift to Rail Transport: Study on the projected effects on GHG emissions and transport volumes", Delft

Chen, G. and Yang, Z. 2010, "Optimizing time windows for managing export container arrivals at Chinese container terminals", Maritime Economics and Logistics, vol. 12, no. 1, pp. 111-126.

Chen, G., Govindan, K. and Yang, Z. 2013, "Managing truck arrivals with time windows to alleviate gate congestion at container terminals", International Journal of Production Economics, vol. 141, no. 1, pp. 179-188.

Clark, X., Dollar, D. and Micco, A. 2004, "Port Efficiency, Maritime Transport Costs, and Bilateral Trade", Journal of Development Economics, vol. 75 2, pp. 417-50.

Cullinane, K. and Khanna, M. 1999, "Economies of Scale in Large Container Ships", Journal of Transport Economics and Policy, vol. 33 2, pp. 185-207.

Department for Transport 2011, "Choosing and Developing a Multi-modal Transport Solution" Freight Best Practice Programme, London.

Estache, A., Goldstein, A. and Pittman, R. 2001, "Privatization and Regulatory Reform in Brazil: the case of freight railways", Journal of Industry, Competition and Trade, vol. 1, no. 2, pp. 203-235.

European Sea Ports Organisation 2012, "Green Guide." Brussels.

Forkenbrock, D.J. 2001, "Comparison of external costs of rail and truck freight transportation", Transportation Research Part A, vol. 35, no. 4, pp. 321-337.

Frankel, E.G. 1999, "The Economics of Total Trans-ocean Supply Chain Management", International Journal of Maritime Economics, vol. 1, no. 2, pp. 61-69.

Fransoo, J.C. and Lee, C. 2012, "The Critical Role of Ocean Container Transport in Global Supply Chain Performance", Production and Operations Management, vol. 22, no. 2, pp. 253-368.

Free and Hanseatic City of Hamburg and Hamburg Port Authority 2012, Hamburg is Staying on Course, the Port Development Plan to 2025, Free and Hanseatic City of Hamburg - State Ministry of Economic Affairs, Transport and Innovation; Hamburg Port Authority, Hamburg.

Gilman, S. 1999, "The size economies and network efficiency of large containerships", Maritime Economics and Logistics, vol. 1, no. 1, pp. 39-59.

Giuliano, G. and O'Brien, T. 2007, "Reducing port-related truck emissions: The terminal gate appointment system at the Ports of Los Angeles and Long Beach", Transportation Research Part D: Transport and Environment, vol. 12, no. 7, pp. 460-473. 
Giuliano, G. and O'Brien, T. 2008, "Extended gate operations at the ports of Los Angeles and Long Beach: a preliminary assessment", Maritime Policy and Management, vol. 35, no. 2, pp. 215-235.

Goel, A. and Kok, L. 2012a, "Efficient scheduling of team truck drivers in the European Union", Flexible services and manufacturing journal, vol. 24, no. 1, pp. 81-96.

Goel, A. and Kok, L. 2012b, "Truck driver scheduling in the United States", Transportation Science, vol. 46, no. 3, pp. 317-326.

Guan, C. and Liu, R.R. 2009, "Container terminal gate appointment system optimization", Maritime Economics and Logistics, vol. 11, no. 4, pp. 378-398.

Hall, P.V. and Jacobs, W. 2010, "Shifting Proximities: The Maritime Ports Sector in an Era of Global Supply Chains", Regional Studies, vol. 44, no. 9, pp. 1103-1115.

Haralambides, H. and Gujar, G. 2011, "The Indian dry ports sector, pricing policies and opportunities for public-private partnerships", Research in Transportation Economics, vol. 33 , no. 1 , pp. 51-58.

Haralambides, H.E. and Londoño-Kent, M.P. 2004, "Supply Chain Bottlenecks: Border Crossing Inefficiencies between Mexico and the United States", International Journal of Transport Economics, vol. 31 2, pp. 183-95.

Haralambides, H.E. 2002, "Competition, Excess Capacity, and the Pricing of Port Infrastructure", International Journal of Maritime Economics, vol. 4 4, pp. 323-47.

Heaver, T., Meersman, H. and van de Voorde, E. 2001, "Co-operation and competition in international container transport: strategies for ports", Maritime Policy and Management, vol. 28, no. 3, pp. 293-305.

Heaver, T.D. 2002, "The Evolving Roles of Shipping Lines in International Logistics", International Journal of Maritime Economics, vol. 4, no.3, pp. 210-30.

Helling, A. and Poister, T.H. 2000, "US maritime ports: trends, policy implications, and research needs", Economic Development Quarterly, vol. 14, no. 3, pp. 300-317.

Hu, L., Shi, X., Voß, S. and Zhang, W. 2011, "Application of RFID technology at the entrance gate of container terminals" in Computational Logistics Springer, vol. 6971, pp. 209-220.

Huynh, N. 2009, "Reducing truck turn times at marine terminals with appointment scheduling", Transportation Research Record: Journal of the Transportation Research Board, vol. 2100, no. 1, pp. 47-57.

International Council on Clean Transportation 2007, 'Air Pollution and Greenhouse Gas Emissions from Ocean-going Ships' ICCT, Washington DC.

Joint Transport Research Centre 2008, 'Port Competition and Hinterland Connections: Summary and Conclusions' Discussion Paper no. 2008-19. Joint Transport Research Centre, OECD / International Transport Forum, Paris.

Kia, M., Shayan, E. and Ghotb, F. 2000, "The importance of information technology in port terminal operations", International Journal of Physical Distribution and Logistics Management, vol. 30, no. 3/4, pp. 331-344.

Knight, I., Newton, W., McKinnon, A.C., Palmer, A. et al. 2008. "Longer and / or Longer and Heavier Goods Vehicles (LHVs): A study of the likely effects if permitted in the UK: Final Report" TRL, Crowthorne.

Konings, R. 2007, "Opportunities to improve container barge handling in the port of Rotterdam from a transport network perspective", Journal of Transport Geography, vol. 15 , no. 6 , pp. 443-454.

Korovyakovsky, E. and Panova, Y. 2011, "Dynamics of Russian dry ports", Research in Transportation Economics, vol. 33, no. 1, pp. 25-34. 
Lee, E., Nam, H. and Song, D. 2012, "Defining Maritime Logistics and its Value" in Marimte Logsitcs a Complete Guide to effective Shippinga and Port Management, eds. D. Song and P.M. Panayides, Kogan Page Publishers, , pp. 9-22.

Leonardi, J., Cullinane, S. and Edwards, J.B. 2013, "The Benefits and Costs of Switching to Alternative Fuels" in McKinnon, A.C., Browne, M. and Whiteing, A. Green Logistics, Kogan Page, London.

Lewis, B.M., Erera, A.L. and White, C.C. 2003, "Optimization approaches for efficient container security operations at transshipment seaports", Transportation Research Record: Journal of the Transportation Research Board, vol. 1822, no. -1, pp. 1-8.

Lirn, T.C. and Wang, J.H. 2010, "The study of threat factors on port risk management: an empirical research in the Kaohsiung Port", Proceedings for International Forum on Maritime Security, pp. 93.

Maloni, M., Paul, J.A. and Gligor, D.M. 2013, "Slow steaming impacts on ocean carriers and shippers", Maritime Economics and Logistics, 15, 151-171.

Mangan, J., Lalwani, C. and Fynes, B. 2008, "Port-centric logistics", International Journal of Logistics Management, vol. 19, no. 1, pp. 29-41.

Marchet, G., Perotti, S. and Mangiaracina, R. 2012, "Modelling the impacts of ICT adoption for inter-modal transportation", International Journal of Physical Distribution and Logistics Management, vol. 42, no. 2, pp. 110-127.

McKinnon, A.C. 2009, "The Present and Future Land Requirements of Logistical Activities", Land Use Policy, vol. 26S, pp. s293-s301.

McKinnon, A.C. 2010, "European Freight Transport Statistics: Limitations, Misinterpretations and Aspirations" ACEA, Brussels.

McKinnon, A.C. 2013, "Decarbonising the deep-sea container supply chain: the possible contribution of port-centric logistics" in: Proceedings of the $13^{\text {th }}$ Annual Conference on Transportation Research Society, Rio de Janiero.

Meersman, H., Pauwels, T., van de Voorde, E. and Vanelslander, T. 2008, "The relation between port competition and hinterland connections: the case of the'Iron Rhine'and the'Betuweroute'", International Forum on Shipping, Ports and Airports (IFSPA 2008)Trade-Based Global Supply Chain and Transport Logistics Hubs: Trends and Future Development.

Monios, J. and Lambert, B. 2013, "Intermodal Freight Corridor Development in the United States." in Dry Ports - A Global Perspective, Challenges and Developments in Serving Hinterlands., eds. R. Bergqvist, G. Wilmsmeier and K. Cullinane, Ashgate Publishing Ltd., Farnham, pp. 197-218.

Monios, J. and Wilmsmeier, G. 2012, "Port-centric logistics, dry ports and offshore logistics hubs: strategies to overcome double peripherality?" Maritime Policy and Management, vol. 39, no. 2, pp. 207-226

Morais, P. and Lord, E. 2006, Terminal appointment system study, .

$\mathrm{Ng}$, A.S.F. 2012, Container flows and empty container repositioning. In: Song, D.W. and Panagotis, P. (eds), Maritime Transport: Contemporary Issues. Edward Elgar Publishing Group Ltd, London.

$\mathrm{Ng}$, A.Y. and Gujar, G.C. 2009, "Government policies, efficiency and competitiveness: The case of dry ports in India", Transport Policy, vol. 16, no. 5, pp. 232-239.

Notteboom, T. 2008, "The Relationship between Seaports and the Inter-modal Hinterland in light of Global Supply Chain: European Challenges" Discussion paper no. 2008-10. Joint Transport Research Centre, OECD / International Transport Forum, Paris. 
Notteboom, T. 2007, "Container river services and gateway ports: Similarities between the Yangtze River and the Rhine River", Asia Pacific Viewpoint, vol. 48, no. 3, pp. 330343.

Notteboom, T. and Rodrigue, J-P. 2008, "Containerisation, Box Logistics and Global Supply Chains: The Integration of Ports and Liner Shipping Networks", Maritime Economics and Logistics, vol. 10, no. 1-2, pp. 152-174.

Notteboom, T. and Rodrigue, J-P., 2007, "Re-assessing port hinterland relationships in the context of global supply chains". In: Wang, J., Notteboom, T., Olivier, D. and Slack, B., (eds), Ports, cities and global supply chains. pp. 51-68. Aldershot: Ashgate.

Notteboom, T.A. 2006, "The Time Factor in Liner Shipping Services", Maritime Economics and Logistics, vol. 8, no. 1, pp. 19-39.

Padilha, F. and Ng, A.K. 2012, "The spatial evolution of dry ports in developing economies: The Brazilian experience", Maritime Economics and Logistics, vol. 14, no. 1, pp. 99-121.

Pittman, R. 2004, "Russian railways reform and the problem of non-discriminatory access to infrastructure", Annals of Public and Cooperative Economics, vol. 75, no. 2, pp. 167192.

Pittman, R. 2007, "Options for restructuring the state-owned monopoly railway", Research in Transportation Economics, vol. 20, pp. 179-198.

Pittman, R. 2013, "The freight railways of the former Soviet Union, twenty years on: Reforms lose steam", Research in Transportation Business and Management, vol. 6, no. 0 , pp. 99-115.

Port of Hong Kong 2012, "Port of Hong Kong: Handbook and Directory" Port of Long Beach 2009, "Air Emissions Inventory" Long Beach

Robinson, R. 2002, "Ports as elements in value-driven chain systems: the new paradigm", Maritime Policy and Management, vol. 29, no. 3, pp. 241-255.

Rodrigue, J. and Notteboom, T. 2010, "Comparative North American and European gateway logistics: the regionalism of freight distribution", Journal of Transport Geography, vol. 18, no. 4, pp. 497-507.

Rodrigue, J. 1999, "Globalization and the synchronization of transport terminals", Journal of Transport Geography, vol. 7, no. 4, pp. 255-261.

Rodrigue, J., Debrie, J., Fremont, A. and Gouvernal, E. 2010, "Functions and actors of inland ports: European and North American dynamics", Journal of Transport Geography, vol. 18, no. 4, pp. 519-529.

Rosa, V. 2007, "Evaluation of the dry port concept from an environmental perspective: A note" Transportation Research Part D: Transport and the Environment, vol. 12, no. 7, pp. 523-527.

Roso, V. and Lumsden, K. 2010, "A review of dry ports", Maritime Economics and Logistics, vol. 12, no. 2, pp. 196-213.

Roso, V. and Rosa, A. 2012, "Dry port in concept and practice" in Maritime Logistics: A Complete Guide to Effective Shipping and Port Management, eds. D. Song and P. Panayides, Kogan Page Publishers, , pp. 179-193.

Roso, V. 2008, "Factors influencing implementation of a dry port", International Journal of Physical Distribution and Logistics Management, vol. 38, no. 10, pp. 782-798.

Roso, V., Woxenius, J. and Lumsden, K. 2009, "The dry port concept: connecting container seaports with the hinterland", Journal of Transport Geography, vol. 17, no. 5, pp. 338-345. 
Schilk, G., Blumel, E., Recagno, V. and Boevé, W. 2007, "Ship, port and supply chain security concepts interlinking maritime with hinterland transport chains", International Symposium on Maritime Safety, Security and Environmental Protection. Athens (Greece), 20th September.

Shi, X., Tao, D. and Voß, S. 2011, "RFID technology and its application to port-based container logistics", Journal of Organizational Computing and Electronic Commerce, vol. 21 , no. 4, pp. 332-347.

Song, D. and Panayides, P.M. 2008, "Global supply chain and port/terminal: integration and competitiveness", Maritime Policy and Management, vol. 35, no. 1, pp. 73-87. Song, D. 2003, "Port Co-opetition in Concept and Practice", Maritime Policy and Management, vol. 30, no. 1, pp. 29-44.

Stahlbock, R. and Voß, S. 2008, "Operations research at container terminals: a literature update", Or Spectrum, vol. 30, no. 1, pp. 1-52.

Suykens, F. and van de Voorde, E. 1998, "A quarter a century of port management in Europe: objectives and tools", Maritime Policy and Management, vol. 25, no. 3, pp. 251261.

Tongzon, J., Chang, Y. and Lee, S. 2009, "How supply chain oriented is the port sector?", International Journal of Production Economics, vol. 122, no. 1, pp. 21-34.

UNECE 1998, UN/LOCODE - Code for ports and other locations, Regulation 16, UN, Geneva.

van Asperen, E., Borgman, B. and Dekker, R. 2011, "Evaluating impact of truck announcements on container stacking efficiency", Flexible Services and Manufacturing Journal, vol. 25, no. 4, pp. 543-556.

van der Horst, M. R. and de Langen, P. W. 2008, 'Coordination in hinterland transportchains: A major challenge for the seaport community'. Maritime Economics and Logistics, 10 , no. 1 108-129.

Veenstra, A., Zuidwijk, R. and van Asperen, E. 2012, "The extended gate concept for container terminals: Expanding the notion of dry ports", Maritime Economics and Logistics, vol. 14, no. 1, pp. 14-32.

Vyas, A D, Patel, D M and Bertram, K M 2013, "Potential for Energy Efficiency Improvement Beyond the Light-Duty-Vehicle Sector" Argonne National Laboratory, Argonne Il.

Wiegmans, B.W., Rietveld, P., Pels, E. and van Woudenberg, S. 2004, "Container Terminals and Utilisation of Facilities", International Journal of Transport Economics, vol. 31 3, pp. 313-39.

Wiegmans, B.W., van der Hoest, A. and Notteboom, T. E. 2008, "Port and terminal selection by deep-sea container operators" Maritime Policy and Management, vol. 35, no. 6, pp. 517-534.

Woodburn, A. 2011, "An Investigation of Container Train Service Provision and Load Factors in Great Britain", European Journal of Transport Infrastructure Research, vol. 11, no. 2, pp. 147165.

Woolford, R. and McKinnon, A.C. 2011b, "Container port emissions: What is included and just how big are they?" in Cherrett, T. (ed) Proceedings of the Logistics Research Network Annual Conference, University of Southampton.

Woolford, R.E. and McKinnon, A.C. 2011a, "Decarbonising the Maritime Supply Chain: the Role of the Shipper", in Notteboom, T. (ed) Current Issues in Shipping, Ports and Logistics, Associated Scientific Publishers, Brussels.

Yang, Y. 2010, "Impact of the container security initiative on Taiwan's shipping industry", Maritime Policy and Management, vol. 37, no. 7, pp. 699-722. 
Yap, W.Y. and Lam, J.S.L. 2013, "80 million-twenty-foot-equivalent-unit container port? Sustainability issues in port and coastal development", Ocean and Coastal Management, vol. 71, no. 0, pp. 13-25.

Yeo, G., Pak, J. and Yang, Z. 2013, "Analysis of dynamic effects on seaports adopting port security policy", Transportation Research Part A: Policy and Practice, vol. 49, pp. 285-301.

Zhao, W. and Goodchild, A.V. 2010, "The impact of truck arrival information on container terminal rehandling", Transportation Research Part E: Logistics and Transportation Review, vol. 46, no. 3, pp. 327-343. 
